\title{
Chemical Constituent of Cinnamom umtamala: An Important Tree Spices
}

\author{
D. Mal ${ }^{1 *}$, S.K. Gharde ${ }^{1}$ and R. Chatterjee ${ }^{2}$ \\ ${ }^{1}$ Lovely Professional University, Jalandhar, India \\ ${ }^{2}$ Uttar Banga Krishi Viswavidyalaya, India
}

*Corresponding author

\section{A B S T R A C T}

Cinnamomum tamala (Buch.-Ham.) Nees and Eberm, commonly known as Tejpatta, is a most important tree spices found in Himalayan region. Its leaves used as spices throughout the world since ancient times. The major

\section{Keywords}

Bay leaf,

Cinnamom

umtamala

Chemical

Constituent

\section{Article Info}

Accepted:

07 March 2018

Available Online:

10 April 2018 component of cinnamon oil is eugenol (4-hydroxy-3-methoxyallylbenzene), ( $\beta$ caryophyllene $(6.6 \%)$, sabinene $(4.8 \%)$, germacrene D $(4.6 \%)$ and curcumenol $(2.3 \%)$. The leaf oil was characterized by a high content of sesquiterpenoids (96.8\%), dominated mainly by furanosesquiterpenoids (79.3). The main constituent of C. tamala leaves are camphene, myrcene, limonene, methyl ether of eugenol and alfapinene. Barks of cinnamon also having medicinal value it possesses cinnamaldehyde which is responsible for its aroma. Medicinally tejpatta oil used as anti-flatulent, diuretic and carminative also it has anti-oxidative potentiality. The present review provides the general information on botanical description of plants, growth habit, chemical composition of cinnamon leaf oil, phytochemical properties, medicinal uses and conservation needs of Cinnamomum tamala.

\section{Introduction}

Bay leaf (Cinnamom umtamala) belong to the family Lauraceae. The genus Cinnamomum comprised of 270 species among which only 20 species and commercially cultivated in India (Anonymous 1950). Bay leaf is popular in different names as in Bengali: Tejpata; Hindi Punjabi and Urdu: Tejpat; Gujarati: Tamalapatra; Oriya: Tejpatra; Tamil:
Talishapattattiri; Telegu: Talisapatri and in Sanskrit: Tamalaka. The bay leaf trees are commercially cultivated throughout the country from tropical region to sub tropical areas of Himalayas at an altitude of 300 to 2400 meters. Bay leaf is also used in South Asia, Australia and Pracific region (Brandis1988; Showkatet al., 2004). Bay leaves or tejpat is regularly used by the Indian people in culinary purposes. Since ancient era 
dry bay leaves are used as spices and green leaves are used in perfumery. It also possessed good medicinal properties. As it stimulate the different digestive enzymes which promotes digestion. Bay leaf is an important constituent of different kind of drugs in pharmaceutical industries.

\section{Botanical description}

Bay leaf is a perennial moderate sized evergreen tree, attaining a height up to 8-12 meters. Stems are rough and brown in color. Barks are soft sometimes produce mucilage. The leaves are $12-20 \mathrm{~cm}$ long and $5-8 \mathrm{~cm}$ in broad. Botanically is a cross pollinated monoecious plant and produce bisexual flowers, where pollination is done by the honey bees. The flowers are whitish in colour and generally occur in last week of March or first week of April. The fruits are drupe and ripens fruits are dark purple in colour. Seed maturity takes place in one year (Sharma et al., 2009).

\section{Taxonomic position of bay leaf}

Kingdom: Plantae

Clade: Angiosperm

Order: Laurales
Family: Lauraceae

Genus: Cinnamomum

Species: tamala

\section{Chemical composition}

Bay leaf is widely used as spices in Indian kitchen for its aroma and flavor as leaves contains an essential oil. The essential oil is extracted after steam distillation of dry leaves. The major component of cinnamon oil is eugenol (4-hydroxy-3-methoxy-allylbenzene), $\beta$-caryophyllene $(6.6 \%)$, sabinene $(4.8 \%)$, germacrene D (4.6\%) and curcumenol (2.3\%). The leaf oil is characterized by a high content of sesquiterpenoids $(96.8 \%)$, dominated mainly by furanosesquiterpenoids $(79.3 \%)$ viz. furanodienone $(46.6 \%)$, curzerenone $(17.6 \%)$, furanodiene $(1.8 \%)$ and curzerene $(1.2 \%)$ (Fischer and dangler 1990; Dighe et al., 2005; Shah and Panchal 2010). The main chemical constituents of bay leaves are camphene, myrcene, limonene, methyl ether of eugenol and alfapinene. Its bark possesses cinnamaldehyde which is responsible for its aroma but the other constituent impart the characteristics odor and flavor. Medicinally tejpat oil used as anti-flatulent, diuretic and carminative (Showlat et al., 2004) (Table 1).

Table.1 Constituents of bay leaf after gas choromatography and mass spectrometry

\begin{tabular}{|c|c|c|c|}
\hline & Low altitude & High-altitude & \multirow{12}{*}{$\begin{array}{l}\text { Annonymous, } 2016 \\
\text { Government of India } \\
\text { Geographical } \\
\text { Indications Journal } \\
\text { No.79 } \\
\text { (January 28, } 2016 \text { / } \\
\text { Magha 08, Saka } 19370\end{array}$} \\
\hline Alfa-pinene & 1.37 & 1.41 & \\
\hline B-pinene & 0.74 & 0.71 & \\
\hline Camphene & 0.55 & 0.26 & \\
\hline Benzaldehyde & 0.32 & 0.54 & \\
\hline P-cymene & 0.99 & 1.20 & \\
\hline L-phellandrene & 0.56 & 0.37 & \\
\hline Alfa-terpeneol & 0.30 & 0.60 & \\
\hline Linalool & 50.40 & 34.82 & \\
\hline CinamylAcetene & 0.43 & 1.16 & \\
\hline Cinnamaldehyde & 34.12 & 46.87 & \\
\hline Bornyl acetate & 1.11 & 0.59 & \\
\hline
\end{tabular}




\section{Medicinal used}

Leaves and barks are carminative astringent and stimulant. Ancient literature revealed that in the first century A.D. dried cinnamon leaves and bark along with honey were prescribed for fever and anemia (Shah and Panchal, 2010). The crushed seeds were mixed with honey andadministered to children against dysentery (Edwards, 1993). C. tamalais an ayurbedicherb mentioned for treatment of bad odour from mouth, dental caries, dark spot on the face, cough tuberculosis. It has been reported that crude drug from unripe fruit of bay leaf is being sold under the name 'Nagkeshara' in different part of India (Vaidya 1971). Green leaves of C. tamala is also used for preparation of sudarshanchoorna and dye (Gaur, 2008).

Numerous studies revealed that bay leaf has great potential as spice in culinary purpose and also as medicinal ingredient for pharmaceutical industry. Owing to its ayurvedic importance and being important constituent of the house hold spices the demand for bay leaf oil or dry leaves is increasing day by day. Thus people are adopting the traditional techniques for cultivation till yet there is no improved package and practices for specific region in India for specific variety. The cataloguing and documentation of different species of Cinnamon is still merger.

\section{Disease and pest}

Glomerella cingulata causes leaf blight and Colletotrichum gloeosporioides a fungus, causes leaf-spot diseases on $C$. tamala. (Khan and Hossain 1985)

\section{References}

Anonymous.1950.Wealth of India, PID, CSIR, New Delhi.
Brandis, D. 1988. Indian Tress: An account of Trees, Shrubs, Woody climbers, Bamboos, and Palms Indigenous or commonly cultivated in the British Indian Empire. Dehradun India, pp.533.

Dhar et al., 2002. Current status and future strategy for development of medicinal plant sector in Uttaranchal, India. Current Science, 83(8):956-964.

Dighe et al., 2005. Quantitative Determination of Eugenol from Cinnamomum tamala Nees and Eberm. Leaf Powder and Polyherbal Fromulation Using Reverse Phase Liquid Chromatography. Chromatographia, 61:43-446.

Edwards, D.M. 1993. The marketing of nontimber forest products from the Himalayas: The Trade between East Nepal and India. In: Rural Develpoment Forestry Network. Network Paper 15b.

Fischer, I.U., Dengler, I.J. 1990. Sensitive high performance liquid chromatographic assay for the determination of eugenol in body fluids. Journal of Chromatography, 525(2):369-377.

Gaur, R.D. 2008. Traditional dye yielding plants of Uttrakhand, India. Natural Products Radiance, 27(2):154-165.

Khan, A. R. and Hossain, M. 1985. Leaf blight of bay-leaf plants, caused by Glomerella cingulata, in Bangladesh. Bangladesh Journal of Botany 14(2): 181-182

Shah, M., Panchal M. 2010 Ethnopharmacological properties of Cinnamomum tamala-a review. International Journal of Pharmaceutical Sciences Review and Research. 5(3):141-144.

Sharma et.al 2009. Seedling emergence and survival in Cinnamomum tamala under varying micro-habitat conditions: conservation impications. Tropical Ecology, 50(1):201-209. 
Showk et al., 2004. Chemical composition of essential oil of Cinnamomum tamala Nees and Eberm. leaves. Flavour and Fragrance Journal, 19:112-114.
Vaidya, B.G. 1971. Some controversial drugs of Indian medicine II. J.Res.Indian.Med. 6(1):95-104.

\section{How to cite this article:}

Mal, D., S.K. Gharde and Chatterjee, R. 2018. Chemical Constituent of Cinnamom umtamala: An Important Tree Spices. Int.J.Curr.Microbiol.App.Sci. 7(04): 648-651. doi: https://doi.org/10.20546/ijcmas.2018.704.073 